DoI: $10.29141 / 2218-5003-2019-10-1-3$

\title{
Evaluation of state support programs for small business: A regional aspect
}

\author{
Mariya V. PODSHIVALOVA, Irina S. PYLAEVA, Nadezhda N. KUZMINA
}

\begin{abstract}
This paper aims to evaluate SME support programs in the context of institutional theory. The methodological basis of the study is the theory of transaction costs, which makes it possible to develop the theoretical aspects of evaluating the effectiveness of state programs by including a new factor in the analysis, i.e. various types of the funds recipients' transaction costs. The authors raise question about the effectiveness of the applied entrepreneurship support programs using the case study of Chelyabinsk and Chelyabinsk region. We analyse the main requirements to applicants, time costs for obtaining subsidies, as well as feedback indicators. On the one hand, we reveal that government bodies impose strict requirements for applicants. On the other hand, the demand for government financial support from SMEs is low. The researchers assess transaction costs of subsidies recipients by transforming time costs into financial costs and conclude that the level of SME transaction costs when submitting applications is insignificant. The main reason behind SME's reluctance to participate in the tender for the allocation of budget funds is a high level of transaction costs of a different nature, that is losses associated with stepping out of the "shadow" when providing information for authorities. The practical application of the results is aimed at improving the adequacy of methods for evaluating the effectiveness of SME support programs for the institutional constraints of the Russian small business.
\end{abstract}

Keywords: small and medium-sized enterprises, supporting program, transaction costs, institutional approach, SME finance.

JEL Classification: H50, E26, 017

Financing: The work was supported by Act of the Government of the Russian Federation No. 211, contract No. 02.A03.21.0011.

Paper submitted: November 15, 2018.

For citation: Podshivalova M.V., Pylaeva I.S., Kuzmina N.N. Evaluation of state support programs for small business: A regional aspect. Upravlenets - The Manager, 2019, vol. 10, no. 1, pp. 28-39. DOI: 10.29141/2218-5003-2019-10-1-3.

\section{INTRODUCTION}

Access to financing is one of the most serious problems for small businesses, not only in Russia, but also in European countries. According to the European Central Bank, access to financing is a pressing problem for $61 \%$ of SME in Greece, $50 \%$ in Spain, $50 \%$ in Italy, $40 \%$ in Portugal ${ }^{1}$. The immediacy of the problems of SME external fund raising is documented by empirical studies around the world [Anderson, Kegels, 1997; Castillo, Mora-Valencia, Perote, 2018; Guinness, Hogan, Powell, 2018; Leonidou, Palihawadana, Theodosiou, 2011; Rupeika-Apoga, 2014; Tülüce, Doğan, 2014; Uesugi, Sakai, Yamashiroc, 2010]. José A. Castillo et al. [2018] find that moral hazard affects default probability of SMEs with collateralized loans. The study by Moreira [2016] that covered 327 SME shows the importance of a firm's normal liquidity for its growth. Rupeika-Apoga [2014] proposes tools for determining financing needs for SMEs using the example of the Baltic States. The study highlights "the need to support the design and evaluation of policy measures and to monitor the implications of financial reforms on SMEs' access to finance". Tülüce and Doğan [2014] prove the importance of foreign direct investment (FDI) in the development of SME. The study of small firms' needs for financing from the standpoint of the institutional approach is presented in [Beck, Demirgüç-Kunt, Maksimovic, 2008; Beck et al., 2006; Bondareva, Zatrochová, 2014; Budina, Garretsen, de Jong, 2000; Gros, Suhrcke, 2000; Peachey, Roe, 2004; Wonglimpiyarat, 2016] using the case study of various countries. However, it is worth noting that, in general, it is rare for foreign researchers to analyse state support as a significant source of SME funding.

${ }^{1}$ European Central Bank. (2013). Survey on the access to finance of small and medium-sized enterprises (SMEs) in the euro area. Available at: www.ecb.europa.eu/stats/ecb_surveys/safe/html/index.en.html.
The positive effect of the SME government support programs has been proven by numerous researchers [Alvarez, 2004; Cansino et al., 2013; Francis, Collins-Dodd, 2004; Freixanet, 2012; Gençtürk, Kotabe, 2001; Jalali, 2012; Lederman, Olarreaga, Zavala, 2016; Leonidou, Palihawadana, Theodosiou, 2011]. In the context of the crisis and poor availability of loans for SME, the role of government support is growing substantially. Prelipcean and Boscoianu [2014] offer governments to respond more actively to the financing constraints faced by SMEs. These are both traditional programs of guaranteed loans, direct lending, microfinance, and new innovative schemes.

Budgetary financing, although a key factor in support programs, is not sufficient. In the structure of such programs, the traditionally substantial role belongs to consulting support. Training, recruiting and R\&D are generally more important for typical SMEs than for larger companies [Wilthagen, 2012]. As a result, free access to various types of consulting support, including marketing and the development of business strategies, is especially pertinent for these firms. This point has an evidence base not only in Russian [llyasova, 2015], but also European [Mrva, Stachová, 2014] and Asian [Aykan, Aksoylu, Sönmez, 2013] studies. At the same time, the authors come to divergent conclusions about the quality of such support in their countries. According to Turkish researchers, there is a clear positive effect of such support, whereas Russian researchers stress obvious gaps in the field of marketing consulting. So, according to Sidorchuk [2012], there is a virtually complete lack of marketing support in terms of competitiveness and SME customer-oriented tendency.

Regarding the effectiveness of the existing system of government support for SME in the Russian Federation, there is some inconsistency between the conclusions of objective 
empirical studies and data of subjective statistics, i.e. surveys of managers of small and medium-sized firms. Thus, according to OPORA Russia, every fourth company participates in regional and local support programs, and most participants highly appreciate the effectiveness of these measures ${ }^{1}$. Having studied SME support in 49 regions of the Russian Federation, Buev et al. [2010] testify the absence of a statistically significant relationship between the volume of support provided by the government and the performance of small businesses. This view is supported by Basareva [2011]. Other authors [Aleshhenko, 2014; Borodushko, 2014; Klimova, 2013] come to similar conclusions about the disappointing results of the measures for stimulating small business and the contradictory nature of business development in Russia.

Thus, the relevance of the tasks to assess the measures of government support for SME is determined by not only the increasing limitation of external financing for small entrepreneurs, but also the shortcomings of the very system of budget allocation.

The purpose of this study is to evaluate the effectiveness of SME state support programs from the standpoint of the institutional approach, viz. the theory of transaction costs. The task of assessing the transaction costs level of applicants for budget funds was solved using the case study of SMEs in Chelyabinsk region.

\section{LITERATURE REVIEW}

The institutional diversity of forms of government support poses the question of their effectiveness and relevance in terms of achieving success and increasing the competitiveness of domestic SMEs [Belova, Barhatov, Pletnyov, 2016]. In the economic literature, we can find different approaches to assessing the effectiveness of government support for small businesses. According to a traditional approach, indicators characterizing the share of small enterprises are used as indicators of feedback: in the total number of enterprises, total turnover, tax revenues, GRP formation and the employed in small enterprises of the total number of employees [Bykova, 2014].

Balekin [2010] suggests assessing the effectiveness of allocated funds to support small businesses according to the effect that the allocated funds produced, based on the following feedback indicators: the number of small businesses; the number of employees in small enterprises; the volume of investment in fixed assets of small enterprises; turnover of small enterprises; wage fund in small enterprises.

A number of economists consider it expedient to include in the analysis output indicators of budget funds spent on implementing measures to promote the development of small businesses. Dadashev et al. [2002] consider such indicators as: the ratio of the annual increase in the volume of sales to the amount of allocated budget funds for their support; the ratio of the annual increase in employee income to the amount of budget funds; the ratio of the volume of payments to the budget system and the amount of government financial support (the indicator of budget efficiency).

\footnotetext{
${ }^{1}$ Entrepreneurial climate in Russia: Index of Opora. 2012. The officia site of the All-Russian public organization of small and medium business «Opora Russia». Available at: www.opora.ru.
}

In the work by Ezhov et al. [2016], a methodology for assessing the effectiveness of government support for small businesses is developed on the basis of calculating the growth in the number of small businesses by 1 million ru bles of budget subsidies using the case of long-term targeted programs for the development of small business, which makes it possible to estimate the return on funds invested in various areas of SMEs activities.

In the study by Mrva and Stachova [2014], the SME government support was assessed by means of the SME number $\subseteq$ indicators, the number of newly born enterprises, SME's contribution to employment, unemployment rate, total profit of organizations.

In 2010, the OECD Working Party on SMEs and entrepreneurship ${ }^{2}$ presented an assessment of government support for small and medium-sized enterprises in the global financial crisis. The effectiveness of support measures was assessed according to subjective statistics. OECD has chosen SME investment activity as significant feedback indicators, along with the number of employees at the enterprise, the threat of bankruptcy, the availability of other (not budgetary) external sources of financing. It noteworthy that the result of this study was a rather high positive assessment of the assistance programs in the countries under review.

Cansino et al. [2013] carried out an economic evaluation of government programs to support the export of SME in Spain based on such indicators as activity, location, sales and number of employees. The analysis showed that the companies involved in the program have improved their ratio of exports to the total sales by about 10 percentage points.

In the group study of the effectiveness of export promotion programs, Francis and Collins-Dodd [2004] rely on methods of subjective statistics: according to surveys, they assess the impact of this program on competencies, strategies and performance of small firms.

An integral method that allows forming a general indicator of the effectiveness of government support for small and medium-sized businesses can be considered as a variety of the traditional approaches to assessment [Bovykina, 2013; Kremin, 2017]. According to Kremin [2017], the integral indicator should include three blocks: socio-economic performance indicators; indicators characterizing the effectiveness of small businesses and those characterizing the contribution of small business in the socio-economic development of the region. According to the author's calculations, in the period of 2008-2014 in the Russian Federation there was a decline in the integral indicator from 3.11 to 2.01, which indicated a decrease in SME effectiveness and an increase in the government's costs for supporting enterprises in this sector.

\section{PROBLEM STATEMENT}

At first glance, the official statistics of the Russian Federation contradict the conclusions of empirical studies: despite the crisis in the economy, the number of small entrepreneurs

${ }^{2}$ OECD Working Party On SMEs And Entrepreneurship (WPSMEE). Available at: www.oecd.org/cfe/smes/Assessment_Government_Support_Programmes.pdf.

\section{I}


(Fig. 1) rapidly increases (Table 1) both in Russia and Chelyabinsk region.

However, the quality of such growth remains questionable, since the criteria for classifying enterprises as SME were revised several times, and many large enterprises "split" their business in order to reduce tax burden.

Against the backdrop of the active growth in the number of SMEs, feedback indicators on support programs for this sector are of interest in the form of the number of applications filed and rejected (Table 2). Until 2017 inclusive, one SME could file several applications for tenders on different types of subsidies, starting from 2018, some changes were introduced: one subsidy to one SME.

At first glance, there is no definite tendency and dependence of the ratio of applications filed to actually granted subsidies over the years. For example, in 2017 there was a very small percentage of subsidies provided, only $28 \%$. This is 22 subsidies out of 79 applications. In 2015, the percentage of subsidies provided was $69 \%$, which, in numerical terms, equaled 24 pieces. Accordingly, in these years almost equal amounts of subsidies were granted. We can conclude that the amount of subsidies granted is limited by a certain number of subsidies, but this is not the case. In 2014 and 2016, the granted subsidies and filed applications were almost twice as large as in the previous years.

Fig. 2 shows that such a rise in the number of filed applications and granted subsidies, are due to changes in the amount of funding for the municipal program. In 2014 and 2016 there were significant subsidies from the federal budget, which made it possible to conduct more tenders. In 2017, there were no subsidies at all, just as well as in 2018. Accordingly, in 2019, a small amount of subsidies is expected.

In Fig. 3, the number of filed applications is related to the number of industrial SMEs and industrial and construction SMEs ${ }^{1}$ as the main "target audience" of support measures. The percentage of small entrepreneurs attempting to receive government support is extremely low in both cases (not more than $5 \%$ and $2.5 \%$, respectively). Perhaps the per-

\footnotetext{
${ }^{1}$ Single Register of Small and Medium Enterprises. Available at: https://rmsp.nalog.ru/search.html?mode=extended\#.
}

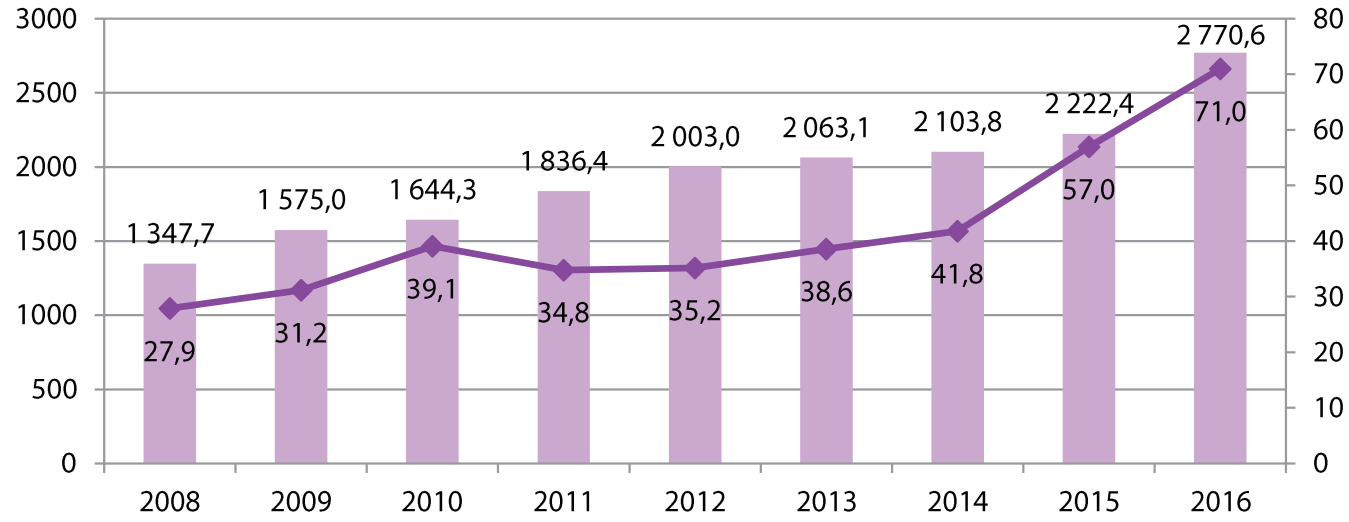

Fig. 1. The dynamics of the number of small enterprises

Note. Compiled by the authors according to the Federal State Statistics Service.

Table 1 - Dynamics of the growth rate of the small enterprises (SE) number in Russia and the Chelyabinsk region

\begin{tabular}{|l|c|c|c|c|c|c|c|c|c|}
\hline \multicolumn{1}{|c|}{ Indicators/year } & 2008 & 2009 & 2010 & 2011 & 2012 & 2013 & 2014 & 2015 & 2016 \\
\hline $\begin{array}{l}\text { Growth rate of SE, } \\
\text { Russia }\end{array}$ & 118,5 & 116,9 & 104,4 & 111,7 & 109,1 & 103,0 & 102,0 & 123,3 & 106,8 \\
\hline $\begin{array}{l}\text { Growth rate of SE, } \\
\text { Chelyabinsk region }\end{array}$ & 107,7 & 111,8 & 125,3 & 89,0 & 101,1 & 109,7 & 108,3 & 136,4 & 124,6 \\
\hline
\end{tabular}

Note. Compiled by the authors according to the Federal State Statistics Service.

Table 2 - Summary data on tenders for granting subsidies to SMEs

\begin{tabular}{|l|c|c|c|c|}
\hline \multicolumn{1}{|c|}{ Indicator/year } & 2014 & 2015 & 2016 & 2017 \\
\hline Applications filed, pieces & 130 & 64 & 132 & 79 \\
\hline Applications rejected, pieces & 51 & 20 & 69 & 57 \\
\hline Subsidies granted, pieces & 79 & 24 & 69 & 22 \\
\hline \% of rejection & $39 \%$ & $31 \%$ & $52 \%$ & $72 \%$ \\
\hline \% of granting & $61 \%$ & $69 \%$ & $48 \%$ & $28 \%$ \\
\hline
\end{tabular}

Note. Compiled by the authors according to the data of Chelyabinsk City Administration. 


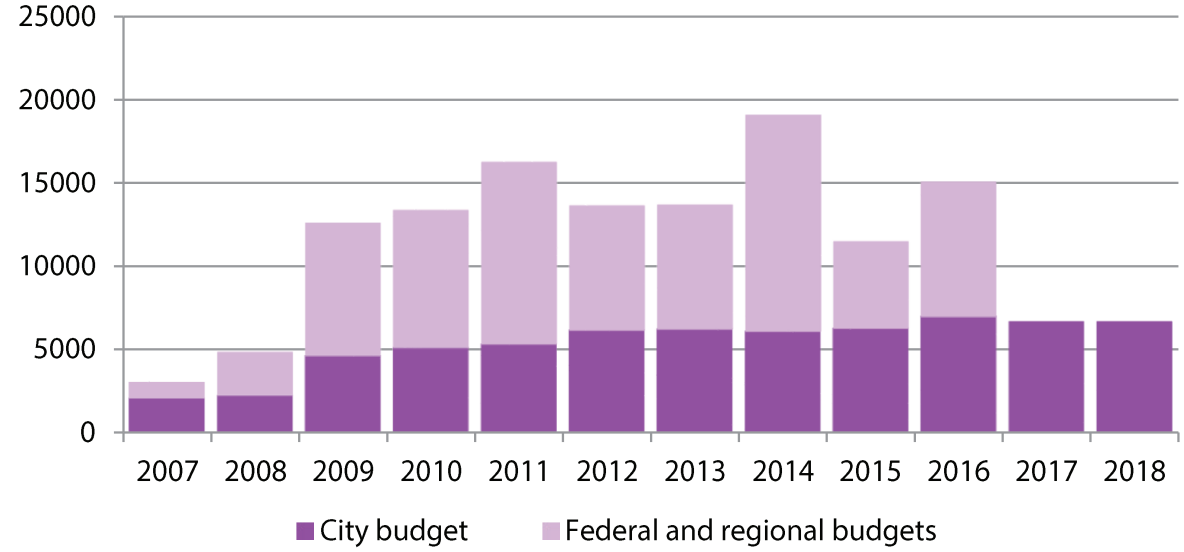

Fig. 2. Volume and sources of the program funding

Note. Compiled by the authors according to the data of Chelyabinsk City Administration.

centage is understated due to the fact that among the small enterprises in the calculation the so-called "fly-by-night companies" and "zero" firms were included. But even if we assume that such firms account for $50 \%$ of the total number (which is unreal, of course), then the percentage will increase two times. It becomes obvious that a very small number of SMEs claims for public funds. The demand for this support tool is essentially non-existent.

In our opinion, the existing approaches to the assessment are rather limited, as they do not provide an opportunity to identify the reasons behind the low efficiency and low relevance of government support measures for SMEs, but only state the facts of quantitative indicators of this sector development. In the paper, we attempt to improve approaches to assessing the effectiveness of governmental support from the standpoint of the institutional approach is made.

\section{DATA AND METHODS}

We believe that the institutional approach is productive, as it allows us to evaluate the assistance schemes offered by the authorities through the level of transaction costs of small enterprises connected with their receiving. The study was conducted at the regional level using the case of Chelyabinsk region. A summary of measures to support small and medium-sized enterprises in the region is presented in Table 3.

We can see that directions and forms of support have been developing in the region only for the last two years

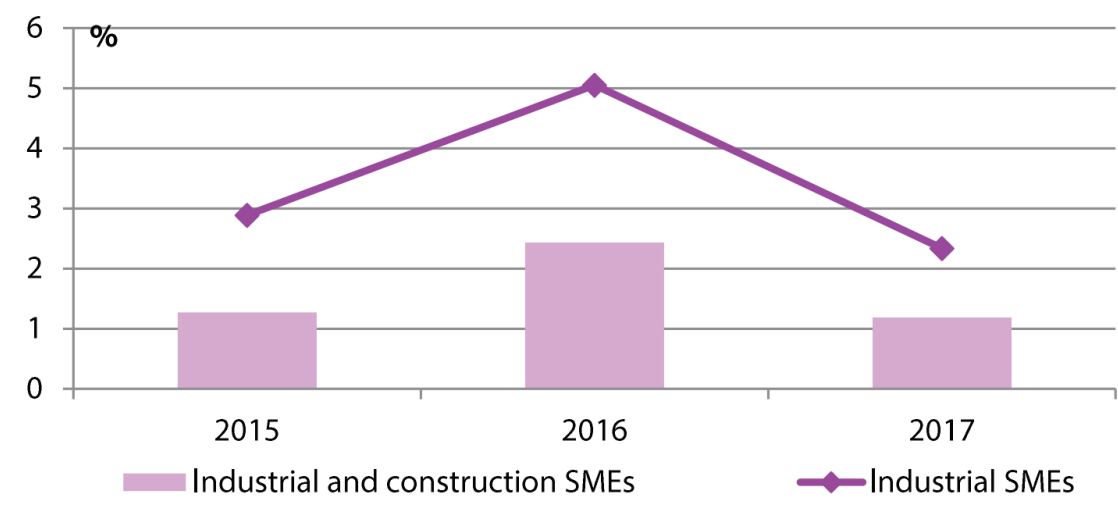

Fig. 3. The ratio of the number of filed applications to the number of industrial and industrial + construction SMEs trade; engines; and currently include such tools as various types of consulting, business train ing, financing, guarantees, support for exports and innovations. At the same time, access restrictions generally concern financial resources only.

The budget of Chelyabinsk city provides eight types of subsidies for SMEs ${ }^{1}$

- payment of interest on loans granted by Russian credit institutions and arranged for purchasing equipment;

- payment of the first instalment when concluding a leasing contract for equipment with Russian leasing organizations in order to create and (or) develop or modernize the production of goods (works, services), including equipment installation costs;

- payment of leasing payments under the equipment leasing contract concluded with Russian leasing organizations in order to create and (or) develop or modernize the production of goods (works, services), including equipment installation costs, with the exception of a portion of the lease payments to cover the lessor's income;

- purchasing equipment in order to create and (or) develop or modernize the production of goods (works, services), excluding equipment designed for wholesale and retail

- participation in Russian exhibitions, fairs;

- website promotion to get to the top positions in search

- implementation of business projects by young entrepreneurs (expenses for acquisition and rent of equipment rent of non-residential premises, professional development, development of entrepreneurial literacy and entrepreneurial competencies of personnel, payment for legal services, purchase of licensed software);

- professional development, improving entrepreneurial literacy and entrepreneurial competencies of personnel.

The selection of subsidies recipients is implemented in the following order. The application for a tender is made, the SME is recognized as the tender participant by the organizer, provided that the conditions listed below are met:

a) availability of information about the SME in the SMEs Unified State Register;

b) registration in the city of Chelyabinsk;

c) the absence of arrears on previously provided budget funds on a returnable basis;

\footnotetext{
${ }^{1}$ City administration of Chelyabinsk. Official site. Available at: https://cheladmin.ru/ru/administraciya-goroda/struktura-upravleniya/komitetekonomiki-g-chelyabinska/maloe-i-srednee-predprinimatelstvo/.
}

Note. Compiled by the authors according to the data of Chelyabinsk City Administration. 
Table 3 - Types of SMEs government support in Chelyabinsk city and Chelyabinsk region

\begin{tabular}{|c|c|c|c|}
\hline $\begin{array}{l}\text { Support infrastructure } \\
\text { object }\end{array}$ & In force & Functions implemented & $\begin{array}{l}\text { Terms of access } \\
\text { to the resource }\end{array}$ \\
\hline $\begin{array}{l}\text { Center for } \\
\text { Entrepreneurship } \\
\text { Support }\end{array}$ & $\begin{array}{l}\text { From May } 2017 \\
\text { to the present time }\end{array}$ & $\begin{array}{l}\text { Consulting assistance, free education on the programs: } \\
\text { "The alphabet of entrepreneurship" for potential and } \\
\text { beginning entrepreneurs; } \\
\text { "School of an entrepreneur" for people who are running } \\
\text { their business }\end{array}$ & \\
\hline $\begin{array}{l}\text { The federal program } \\
\text { "You are an } \\
\text { entrepreneur" }\end{array}$ & & Training & Application + testing \\
\hline $\begin{array}{l}\text { Multifunctional } \\
\text { Business Center }\end{array}$ & \multirow{6}{*}{$\begin{array}{l}\text { From } 2017 \\
\text { to the present time }\end{array}$} & $\begin{array}{l}\text { A full range of services for SMEs: consultating, } \\
\text { registration of sole traders and legal entities, cadastral } \\
\text { register and cartography, verification of violations, } \\
\text { issuance of permits }\end{array}$ & \\
\hline Guarantee Center & & Security for loans, bank guarantees and leasing & $\begin{array}{l}\text { At least } 30 \% \text { of own funds } \\
\text { from the amount of liabilities }\end{array}$ \\
\hline $\begin{array}{l}\text { Export Support } \\
\text { Center }\end{array}$ & & Support to export-oriented entities & \\
\hline $\begin{array}{l}\text { Center for Cluster } \\
\text { Development }\end{array}$ & & Consulting assistance & \\
\hline $\begin{array}{l}\text { Industrial } \\
\text { Development Fund }\end{array}$ & & $\begin{array}{l}\text { Provision of targeted loans at a reduced rate, } \\
\text { information and consulting services }\end{array}$ & \\
\hline $\begin{array}{l}\text { Regional Engineering } \\
\text { Center }\end{array}$ & & $\begin{array}{l}\text { Development projects support of manufacturing } \\
\text { enterprises with co-financing of engineering and } \\
\text { consulting services of third-party organizations }\end{array}$ & $\begin{array}{l}\text { Percentage of co-financing } \\
\text { by the enterprise not less } \\
\text { than } 20 \%\end{array}$ \\
\hline $\begin{array}{l}\text { Agency for } \\
\text { Investment } \\
\text { Development }\end{array}$ & $\begin{array}{l}\text { From } 2016 \\
\text { to the present time }\end{array}$ & $\begin{array}{l}\text { Ensuring interaction with investment and venture } \\
\text { funds, etc., consulting assistance, support for } \\
\text { investment projects }\end{array}$ & \\
\hline Microfinance Center & $\begin{array}{l}\text { From } 2017 \\
\text { to the present time }\end{array}$ & $\begin{array}{l}\text { Issue of loans (up to } 1 \text { million rubles at } 10 \% \text { per annum, } \\
\text { up to } 1 \text { year) }\end{array}$ & \\
\hline $\begin{array}{l}\text { The program of } \\
\text { affordable investment } \\
\text { lending }\end{array}$ & $\begin{array}{l}\text { From } 2017 \\
\text { to the present time }\end{array}$ & Easy-term Ioan & $\begin{array}{l}\text { Realization of investment } \\
\text { projects, creation or } \\
\text { acquisition of fixed assets, } \\
\text { including construction }\end{array}$ \\
\hline $\begin{array}{l}\text { Business navigator - } \\
\text { free Internet resource } \\
\text { (JSC "Corporation" } \\
\text { SME ") }\end{array}$ & $\begin{array}{l}\text { From } 2016 \\
\text { to the present time }\end{array}$ & Consulting assistance & \\
\hline $\begin{array}{l}\text { State-financed } \\
\text { Institution of the } \\
\text { Chelyabinsk region } \\
\text { "Innovative business } \\
\text { incubator" }\end{array}$ & $\begin{array}{l}\text { From } 2007 \\
\text { to the present time }\end{array}$ & Property support of beginning entrepreneurs & $\begin{array}{l}\text { Tender (duration of up } \\
\text { to } 3 \text { years, innovative/ } \\
\text { general activity (subjects of } \\
\text { youth, social and women } \\
\text { entrepreneurship); } \\
\text { availability of a } \\
\text { documentation package; } \\
\text { provision of a business plan, } \\
\text { absence of debts on tax } \\
\text { payments }\end{array}$ \\
\hline Property support & $\begin{array}{l}\text { From } 2010 \\
\text { to the present time }\end{array}$ & $\begin{array}{l}\text { Transfering government or municipal property into } \\
\text { possession and (or) use (on a paid/gratuitous basis or } \\
\text { on preferential terms) }\end{array}$ & \\
\hline $\begin{array}{l}\text { Youth innovation } \\
\text { creativity centers }\end{array}$ & From 2018 & Material and technical, economic, information base & \\
\hline $\begin{array}{l}\text { Subsidies at the local } \\
\text { level }\end{array}$ & $\begin{array}{l}\text { From } 2007 \\
\text { to the present time }\end{array}$ & Reimbursement of a part of the expenses incurred & $\begin{array}{l}\text { Tender for the best } \\
\text { performance indicators }\end{array}$ \\
\hline $\begin{array}{l}\text { Subsidies at the } \\
\text { regional level }\end{array}$ & $\begin{array}{l}\text { From } 2005 \\
\text { to the present time }\end{array}$ & Reimbursement of a part of the expenses incurred & $\begin{array}{l}\text { Tender for the best } \\
\text { performance indicators }\end{array}$ \\
\hline
\end{tabular}

Source: compiled by the authors according to the data of Chelyabinsk City Administration. 
d) absence of arrears in payment of taxes, fees, penalties, fines, interest and other obligatory payments to budgets of all levels and state non-budgetary funds;

e) payment of taxes, fees and other obligatory payments in the current and previous year to budgets of all levels and state non-budgetary funds;

f) non-existence at the stage of reorganization, liquidation, bankruptcy, unrestricted legally in accordance with the legislation of the Russian Federation;

g) the availability of permanent jobs as of January 1 of the current year, the presence of at least two jobs - for SME that are applying for a loan subsidy and/or a subsidy on lease payments and/or subsidies for payment of the first instalment and (or) subsidies for the acquisition of equipment;

h) payment of average monthly wages to employees for the year preceding the year of applying for a subsidy in the amount not less than the minimum wage in the organizations of the extrabudgetary sector of the economy approved by the regional minimum wage agreement in Chelyabinsk region for the corresponding year (in 2017 this was 9700 rubles) ${ }^{1}$;

i) provision for reimbursement of costs for which similar financial support was not provided;

j) the consent of the head and representative of the SME for the processing of personal data;

k) investing SME's own funds in the purchase of equipment in the current and (or) previous year (leasing).

Criteria for competitive selection are:

1) budgetary efficiency (tax burden): the ratio of the volume of tax revenues from SMEs to budgets of all levels and insurance contributions in the year preceding the year of applying for a subsidy, to the volume of sales of goods, works, services (revenues) for the same period. Table 4 presents the ratio of points and different levels of tax burden in the sectoral context;

2) social efficiency: the ratio of the average monthly wage per employee for the year preceding the year of applying for

\footnotetext{
${ }^{1}$ Labour Inspection. Available at: http://trudinspection.ru/mr/ mrot-ch/.
}

the subsidy to the value of the minimum wage in organizations of the extrabudgetary sector of the economy approved by the regional minimum wage agreement in the Chely abinsk region for the corresponding year (Table 5);

3) social responsibility: the availability of a collective agreement according to Table 6;

4) the importance of the type of economic activity ac cording to the All-Russian Classifier of Economic Activities (Table 7);

5) the number of subsidies received (Table 8); the year of applying for a subsidy (Table 9).

The tender winners are chosen by the tender committee after awarding the points to the participants of the tender according to the criteria of the competitive selection. The number of points of each participant is summed up by all criteria, and the winners of the tender are identified by the largest sum of points scored.

\section{RESULTS}

Having analysed the data of Tables 4-9, we can summarize that the allocation of budget funds on a competitive basis is focused on a rather narrow range of SMEs:

- enterprises involved in manufacturing and scientific developments; considering that the structure of the SMEs has not changed for the past 20 years, only every 10 th enterprise today can be attributed to this sphere ${ }^{2}$; for the sake of justice, it should be noted that these enterprises are in need for support for the development of an innovative and import-substituting economy;

- enterprises that have the largest allocations to the budget; in fact, if a subsidy is received by a SME, it is expected to be repaid in the form of tax deductions. Considering that many SMEs apply special taxation regimes, enterprises with a general taxation system are in a priority position;

\footnotetext{
${ }^{2}$ Russian Federal State Statistics Service. Small and medium entrepreneurship. Available at: www.gks.ru/wps/wcm/connect/rosstat_main/ rosstat/ru/statistics/publications/catalog/doc_1139841601359.
}

Table 4 - Ratio of tax burden and points

\begin{tabular}{|c|c|c|c|c|}
\hline \multirow{2}{*}{ Sections, subsections of economic activities } & \multicolumn{4}{|c|}{ Number of points } \\
\hline & 0 & 2 & 4 & 6 \\
\hline Manufacturing, \% & Less than 1.0 & From 1.0 to 4.0 & From 4.0 to 7.1 & Over 7.1 \\
\hline Construction, \% & Less than 1.0 & From 1.0 to 6.0 & From 6.0 to 12.2 & Over 12.2 \\
\hline Production and distribution of electricity, gas and water, \% & Less than 1.0 & From 1.0 to 2,8 & From 2.8 to 4.8 & Over 4.8 \\
\hline Transport and communication, \% & Less than 1.0 & From 1.0 to 4.0 & From 4.0 to 9.7 & Over 9.7 \\
\hline $\begin{array}{l}\text { Wholesale and retail trade, repair of motor vehicles, motor- } \\
\text { cycles, household goods and personal items, } \%\end{array}$ & Less than 1.0 & From 1.0 to 1,7 & From 1.7 to 2.4 & Over 2.4 \\
\hline Hotels and restaurants, $\%$ & Less than 1.0 & From 1.0 to 6.0 & From 6.0 to 12.2 & Over 12.2 \\
\hline Operations with real estate, renting, \% & Less than 1.0 & From 1.0 to 10.0 & From 10.0 to 22.2 & Over 22.2 \\
\hline Agriculture, hunting and forestry, $\%$ & Less than 1.0 & From 1.0 to 2.0 & From 2.0 to 3.6 & Over 3.6 \\
\hline Fishery, fish farming, \% & Less than 1.0 & From 1.0 to 4.0 & From 4.0 to 7.6 & Over 7.6 \\
\hline Provision of other communal, social and personal services, \% & Less than 1.0 & From 1.0 to 11,5 & From 11.5 to 23.09 & Over 23.9 \\
\hline Activities not included in the above sections, $\%$ & Less than 1.0 & From 1.0 to 4.0 & From 4.0 to 9.7 & Over 9.7 \\
\hline
\end{tabular}




\begin{tabular}{|c|c|}
\hline Coefficient & Number of points \\
\hline Over 4.0 & 6 \\
\hline From 3.5 to 4.0 & 5 \\
\hline From 3.0 to 3.5 & 4 \\
\hline From 2.5 to 3.0 & 3 \\
\hline From 2.0 to 2.5 & 2 \\
\hline From 1.0 to 2.0 & 1 \\
\hline From than 1.0 & 0 \\
\hline
\end{tabular}

Table 6 - Ratio of condition and points

\begin{tabular}{|l|c|}
\hline \multicolumn{1}{|c|}{ Collective agreement availability } & Number of points \\
\hline Collective agreement is available & 3 \\
\hline Collective agreement is not available & 0 \\
\hline
\end{tabular}

Table 7 - Ratio of condition and points

\begin{tabular}{|l|c|}
\hline \multicolumn{1}{|c|}{ Sections, subsections of economic activities } & Number of points \\
\hline $\begin{array}{l}\text { Manufacturing processes; } \\
\text { scientific research and development }\end{array}$ & 6 \\
\hline $\begin{array}{l}\text { Education, Public health service and provision of social services; } \\
\text { provision of other communal, social and personal services; } \\
\text { provision of other services }\end{array}$ & 5 \\
\hline $\begin{array}{l}\text { Production and distribution of electricity, gas and water; } \\
\text { construction, transport and communications }\end{array}$ & 4 \\
\hline Agriculture, hunting and forestry, fisheries, fish farming & 3 \\
\hline Hotels and restaurants & 2 \\
\hline $\begin{array}{l}\text { Wholesale and retail trade; repair of motor vehicles; motorcycles; } \\
\text { household products and personal items; real estate transactions; } \\
\text { rent of machinery and equipment without an operator; rental of } \\
\text { household goods and personal items; activities not included in the } \\
\text { above sections (subsections) }\end{array}$ & 1 \\
\hline
\end{tabular}

Table 8 - Ratio of condition and points

\begin{tabular}{|l|c|}
\hline $\begin{array}{c}\text { The amount of received subsidies of the type } \\
\text { indicated in the application within the municipal program for } \\
\text { the last 3 years preceding the year of applying }\end{array}$ & Number of points \\
\hline Did not receive a subsidy of this type & 6 \\
\hline Received a subsidy of this type 1 time & 4 \\
\hline Received a subsidy of this type 2 times & 2 \\
\hline Received a subsidy of this type 3 times & 0 \\
\hline
\end{tabular}

Table 9 - Ratio of condition and points

\begin{tabular}{|c|c|c|c|}
\hline For microenterprises & $\begin{array}{c}\text { For small } \\
\text { enterprises }\end{array}$ & $\begin{array}{c}\text { For medium-sized } \\
\text { enterprises }\end{array}$ & \multirow{2}{*}{ Number of points } \\
\cline { 1 - 3 } Preservation and creation of jobs, units & 6 \\
\hline 5 and more & 12 and more & 19 and more & 5 \\
\hline 4 & $9-11$ & $13-18$ & 4 \\
\hline 3 & $6-8$ & $8-12$ & 3 \\
\hline 2 & $3-5$ & $4-7$ & 2 \\
\hline 2 & $1-2$ & $1-3$ & 1 \\
\hline \multicolumn{3}{|c|}{ Preservation of jobs } \\
\hline \multicolumn{3}{|c|}{ Non-preservation of jobs (release of employees) } & 0 \\
\hline
\end{tabular}

- enterprises with a collective agreement available, preservation and creation of jobs, with a high ratio of the average salary to the minimum pay. Taking into account the well-known aptitude of the Russian SMEs for so-called «tax imization» due to concealment of the taxable payroll d, it can be assumed that this item of the requirements (a) efforts, as it is assumed that in the normal course of busi ness, these documents should be structured and can be easness, these documents should be structured and can be easanalysis of the level of transaction costs, these time costs are not included.

The most difficult documents to collect are from the first block: a statement on the type of subsidy (the company card is filled in according to the established form, it takes 60 minutes, the transfer of the whole package of documents takes about 40 minutes); power of attorney from the SME (if the application with the attached documents is submitted by the SME); the original and a copy of the passport of the person providing the documents.

Below you may find a general list of requested documents, which at first glance looks impressive, but in fact the collection of documents is not so complicated.

1. Information from the Single Register of Small and Medium Enterprises.

2. Extract from the Unified State Register of Legal Entities or Unified State Register of Individual Entrepreneurs (it is enough to download the form from the Internet source, it takes 5 minutes).

3. Documents confirming the absence of tax and insurance payments (they are processed online, it takes 5 minutes, reception in 5 days and 30 minutes waiting for the reception).

4. A copy of the balance sheet and a report about the financial performance of the activity (copying the documents, 15 minutes).

5. A copy of the form «Information on the average number of employees» for 2 years (copying of existing documents, 15 minutes). 
6. Copies of the calculation of accrued and paid insurance premiums (copying the documents, 30 minutes).

7. Copies of documents confirming the amount of actually paid taxes to budgets of all levels (copying the documents, time depending on the volume of documents, about 30 minutes).

8. A copy of the document confirming the existence of a collective agreement concluded between employees and the employer-SME, which has passed the notification registration (copying the documents, 15 minutes).

On average, the collection of basic documents for applying for a tender takes about 250 minutes and 5 days of waiting for a certificate from the tax authority; confirming the reimbursement expenses takes from 60 to 180 minutes. Additional fees and charges are not provided.

Table 10 assesses the level of transaction costs that fall on the SME in the case of participation in a tender for receiving budgetary funds.

The number " 12 " in the Table means the number of necessary documents and certificates to participate in the tender, and after the " + " sign the number of documents confirming the type of expenses incurred is indicated. After the " $=$ sign, the total number of documents required to participate in the tender for the subsidy is displayed. Transaction costs of entrepreneurs in value terms are estimated through the amount of the minimum wage in Chelyabinsk region in 2018, i.e. 9489 rubles ${ }^{1}$. The calculation also includes the waiting time for processing the documents.

Thus, participation in the tender requires from the SME, firstly, to meet the requirements specified above, and secondly, the preparation of necessary documents, transaction costs, the formation of which is generally insignificant (in monetary terms, only 2431 rubles).

\footnotetext{
${ }^{1}$ Federal Law No. 82-FZ of June 19, 2000.
}

Table 10 - The evaluation of transaction costs for participation in the tender for subsidies

\begin{tabular}{|l|c|c|c|}
\hline \multicolumn{1}{|c|}{ Type of a subsidy } & $\begin{array}{c}\text { Number of documents } \\
\text { for the tender, pieces }\end{array}$ & $\begin{array}{c}\text { Number of } \\
\text { hours worked, } \\
\text { hours }\end{array}$ & $\begin{array}{c}\text { Transaction costs, } \\
\text { rubles }\end{array}$ \\
\hline Loan subsidy & $12+4=16$ & & \\
\cline { 1 - 2 } $\begin{array}{l}\text { Subsidy for the first } \\
\text { installment }\end{array}$ & $12+5=17$ & & \\
\cline { 1 - 2 } $\begin{array}{l}\text { Subsidy on leasing } \\
\text { payments }\end{array}$ & $12+5=17$ & \multirow{2}{*}{44,2} & \\
\cline { 1 - 2 } $\begin{array}{l}\text { Subsidy for the purchase } \\
\text { of equipment }\end{array}$ & $12+4=16$ & \\
\cline { 1 - 2 } $\begin{array}{l}\text { Subsidy for participation } \\
\text { in a fair }\end{array}$ & $12+3=15$ & \\
\cline { 1 - 2 } $\begin{array}{l}\text { Subsidy for website } \\
\text { promotion }\end{array}$ & $12+4=16$ & & \\
\cline { 1 - 2 } $\begin{array}{l}\text { Subsidy to the subjects of } \\
\text { youth entrepreneurship }\end{array}$ & $12+2=14$ & & \\
\cline { 1 - 2 } $\begin{array}{l}\text { Subsidy on professional } \\
\text { development }\end{array}$ & $12+4=16$ & & \\
\hline
\end{tabular}

Note. Compiled by the authors.
To sum up, in order to receive a subsidy, a SME should fulfill a lot of conditions, from receiving certificates and documents from official sources to full compliance with requirements. However, the level of these transaction costs cannot be regarded as significant.

\section{DISCUSSION AND IMPLICATION}

What is the reason behind the low effectiveness of government support schemes for SMEs? We believe that the current support mechanism is doomed to a low demand from the $\subseteq$ SMEs, which was identified above. First of all, this is due to the high level of transaction costs, but not those that the firm bears in passing the tender for receiving budget funds, those associated with the loss of benefits from being in the "shadow".

Essentially, in order to get the highest score for the tender, small entrepreneurs have to solve the dilemma: either step out of the "shadow" and get a subsidy or stay in the "shadow", rely on informal sources of financial assistance (money from relatives, friends, consumer loans of founders). Given that it is impossible to receive subsidies every year for SMEs, as the demands of the tender are a priority for new applicants, the attractiveness and profitability of opening a business to the authorities is significantly reduced.

Another reason behind the low demand for government support programs among SMEs is rather strict requirements for applicants. Small entrepreneurs are prejudiced that they will not be able to pass all the necessary conditions for obtaining financing, and therefore they do not try to seek assistance. A self-reliance combined with a low confidence in the government is a distinctive feature of Russian small entrepreneurs, which literally ties them to the shadow economy. Until this mindset is corrected, no effective measures, even objective of the government support, will be in demand in the SME sector.

Further directions and tasks of research in this area are aimed at improving the tools for institutional analysis of SME government support programs, as well as conducting empirical research in other regions of the Russian Federation and countries with similar institutional constraints.

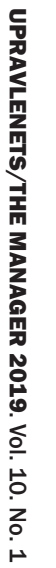


Aleshhenko V.V. (2014). [Prostranstvennaja asimmetrija urovnja razvitija predprinimatel'stva i gosudarstvennogo finansirovanija programm podderzhki malogo i srednego biznesa v Rossii]. In: Dvadtsatye aprel'skie ekonomicheskie chteniya: Materialy mezhdunar. nauch.-prakt. konf. [The 20th April Economic Readings. Proc. of Int. sci.-pract. conf.]. Omsk: Omskij filial Finansovogo universiteta pri Pravitel'stve RF. Pp. 8-11.

Balekin E.V. (2010). Metodicheskie aspekty gosudarstvennogo upravlenija razvitiem i podderzhkoj promyshlennogo malogo predprinimatel'stva v Moskve [Methodical aspects of state management of development and support of industrial small business in Moscow]. Vestnik Moskovskogo gosudarstvennogo oblastnogo universiteta. Serija: Ekonomika - Bulletin of the Moscow Region State University. Series: Economics, vol. 2, pp. 137-141.

Basareva V.G. (2010). [SME state support: help or an institutional trap?]. In: Yasin E.G. (ed.) XI Mezhdunar. nauch. konf. po problemam razvitiya ehkonomiki i obshchestva (Moskva, 6-8 apr. 2010 g.) [Proc. of the 11th Int. sci. conf. on the problems of the economic and social development. Moscow, April 6-8, 2010]. Moscow: HSE Publishing House. Part. 2, pp. $171-179$.

Belova I.A., Barhatov V.I., Pletnyov D.A. (2016). [The impact of small and medium-sized business support programs in Russia on their successful functioning]. In: Metodologija ustojchivogo ekonomicheskogo razvitija v uslovijah novoj industrializacii: sb. tr. mezhdunar. nauch. konf. [Methodology of sustainable economic development in the context of new industrialization. Proc. of Int. sci. conf.]. Moscow: Antikva. Pp. 147-151.

Bovykina M.G. (2013). [On the issue of assessing the effectiveness of state support for small businesses]. In: Ledencovskie chteniya. Biznes. Nauka. Obrazovanie: Materialy III Mezhdunar. nauch.-prakt. konf. [Ledentsov's Readings. Business. Science. Education. Proc. of the 3rd Int. sci.-pract. conf.]. Vologda. Pp. 383-390.

Borodushko I.V. (2014). Russian small business: Lawful regulation and state support [Rossijskij malyj biznes: pravovoe regulirovanie i gosudarstvennaja podderzhka]. Vestnik Sankt-Peterburgskoj juridicheskoj akademii - Bulletin of Saint Petersburg Law Academy, vol. 4, pp. 44-47.

Buev V.V., Saydullaev F.S., Shamray A.A. (2010). Indeks razvitiya malogo predprinimatel'stva [Small business in the regions of Russia in 2009]. Moscow: ANO NISIPP. P. 12.

Bykova N.V. (2014). The modern approach to evaluating the efficiency of state support for small scale business [Sovremennyj podhod k ocenke jeffektivnosti gosudarstvennoj podderzhki malogo predprinimatel'stva]. Vestnik Leningradskogo gosudarstvennogo universiteta im. A.S. Pushkina - Bulletin of Pushkin Leningrad State University, vol. 4, pp. 107-115.

Dadashev A., Golovjackaja I., Lazurenko S., Neshitoj A. (2002). Efficiency of support of small business [Jeffektivnost' podderzhki malogo predprinimatel'stva]. Voprosy ekonomiki - The Russian Journal of Economy, vol. 7, pp. 127-135.

Ezhov A.N., Lukin S.V., Il'ina L.N., Zhura S.E., Smirnova I.G. (2016). Assessment of the government support efficiency of small businesses in modern conditions [Ocenka jeffektivnosti gosudarstvennoj podderzhki malogo biznesa v sovremennyh uslovijah]. Biznes. Obrazovanie. Pravo - Business. Education. Law, vol. 2, pp. 29-34.

Ilyasova A.V. (2015). The effectiveness of regional programs of support of small and medium business in the Penza region [Jeffektivnost' regional'nyh programm podderzhki malogo i srednego biznesa v Penzenskom regione]. Zhurnal XXI vek: itogi proshlogo i problemy nastojashhego pljus - XXI Century: Resumes of the Past and Challenges of the Present plus, no. 6 , pp. 330-334.

Klimova M.V. (2013). Small business in Russia: state support or ruin? [Malyj biznes v Rossii: gosudarstvennaja podderzhka ili razorenie?]. Nacional'nye interesy: prioritety i bezopasnost' - National Interests: Priorities and Security, vol. 31, pp. 49-55.

Kremin A.E. (2017). Assessment Methodology of State Support Efficiency of Small Entrepreneurship in the Region [Metodika ocenki jeffektivnosti gosudarstvennoj podderzhki malogo predprinimatel'stv a v regione]. Problemy razvitija territorii - Problems of Territorial Development, vol. 3, pp. 46-61.

Sidorchuk R.R. (2012). The state and public support for small enterprise (SME) in Russia [Gosudarstvennaja i obshhestvennaja podderzhka malyh i srednih predprijatij (MSP) v Rossii]. Marketing MVA. Marketingovoe upravlenie predprijatiem - Marketing Management in a Company, no. 2, pp. 4-25.

Alvarez R. (2004). Sources of export success in small- and medium-sized enterprises: The impact of public programs. International Business Review, vol. 13(3), pp. 383-400.

Anderson R., Kegels C. (1997). Finance and Investment in Transition: Czech Enterprises, 1993-1994. William Davidson Institute Working Papers Series 164, William Davidson Institute at the University of Michigan. Available at: https://ideas.repec. org/p/wdi/papers/1997-164.html.

Aykan E., Aksoylu S., Sönmez E. (2013). Effects of Support Programs on Corporate Strategies of Small and Medium-sized Enterprises. Procedia - Social and Behavioral Sciences, vol. 99, pp. 938-946.

Beck T., Demirgüç-Kunt A., Maksimovic V. (2008). Financing Patterns Around the World: Are Small Firms Different? Journal of Financial Economics, vol. 89, pp. 467-487.

Beck T., Demirgüç-Kunt A., Laeven L., Maksimovic V. (2006). The Determinants of Financing Obstacles. Journal of International Money and Finance, vol. 25(6), pp. 932-952.

Bondareva I., Zatrochová M. (2014). Financial Support for the Development of SMEs in the Slovak Republic. Procedia Social and Behavioral Sciences, vol. 110, pp. 541-548.

Budina N., Garretsen H., Jong E. de (2000). Liquidity Constraints and Investment in Transition Economies: The Case of Bulgaria. Economics of Transition, vol. 8, pp. 453-475. 
Cansino J.M., Lopez-Melendo J., Pablo-Romero M.D.P., Sánchez-Braza A. (2013). An economic evaluation of public programs for internationalization: The case of the Diagnostic program in Spain. Evaluation and Program Planning, vol. 41, pp. 38-46.

Castillo J.A., Mora-Valencia A., Javier Perote J. (2018). Moral hazard and default risk of SMEs with collateralized loans. Finance Research Letters, vol. 26 (Sept.), pp. 95-99. Available at: https://doi.org/10.1016/j.frl.2017.12.010.

Francis J., Collins-Dodd C. (2004). Impact of export promotion programs on firm competencies, strategies and performance: The case of Canadian high-technology SMEs. International Marketing Review, vol. 21(4-5), pp. 474-495.

Freixanet J. (2012). Export promotion programs: Their impact on companies' internationalization performance and competitiveness. International Business Review, vol. 21(6), pp. 1065-1086.

Gençtürk E.F., Kotabe M. (2001). The effect of export assistance program usage on export performance: A contingency explanation. Journal of International Marketing, vol. 9(2), pp. 51-72.

Gros D., Suhrcke M. (2000). Ten Years After: What is Special About Transition Countries? European Bank Working Paper, vol. 56. Available at: http://hdl.handle.net/10419/19465.

Guinness G.Mc., Hogan T., Powell R. (2018). European trade credit use and SME survival. Journal of Corporate Finance, vol. 49, pp. 81-103.

Jalali S.H. (2012). The effect of export promotion programs on export performance: Evidence from Iranian food manufacturers. International Journal of Business and Globalisation, vol. 9(2), pp. 122-133.

Lederman D., Olarreaga M., Zavala L. (2016). Export promotion and firm entry into and survival in export markets. Canadian Journal of Development Studies, vol. 37(2), pp. 142-158.

Leonidou L.C., Palihawadana D., Theodosiou M. (2011). National export-promotion programs as drivers of organizational resources and capabilities: Effects on strategy, competitive advantage, and performance. Journal of International Marketing, vol. 19(2), pp. 1-29.

Moreira D.F. (2016). The Microeconomic Impact on Growth of SMEs When the Access to Finance Widens: Evidence from Internet \& High-tech Industry. Procedia - Social and Behavioral Sciences, vol. 220, pp. 278-287.

Mrva M., Stachová P. (2014). Regional Development and Support of SMEs - How University Project can Help. Procedia Social and Behavioral Sciences, vol. 110, pp. 617-626.

Peachey S., Roe A. (2004). Access to finance, Oxford Policy Management. Available at: www.microfinancegateway.org/ gm/document-1.9.29564/22078_access_2_finance.pdf.

Prelipcean G., Boscoianu M. (2014). A Hybrid Framework for SME Financing Based on the Mix between Governmental Support and the Use of a Specialized Investment Fund in the Actual Context of a Slow Recovery after Crises and Turbulences. Procedia Economics and Finance, vol. 15, pp. 738-745.

Rupeika-Apoga R. (2014). Financing in SMEs: Case of the Baltic States. Procedia - Social and Behavioral Sciences, no. 150, pp. 116-125.

Tülüce N.S., Doğan I. (2014). The Impact of Foreign Direct Investments on SMEs' Development. Procedia - Social and Behavioral Sciences, vol. 150, pp. 107-115.

Uesugi I., Sakai K., Yamashiroc G.M. (2010) The Effectiveness of Public Credit Guarantees in the Japanese Loan Market. Journal of the Japanese and International Economies, vol. 24(4), pp. 457-480.

Wilthagen T. (2012). SMEs unite! In: Hofheinz P., Mettler A. SMEs in the single market - A growth agenda for the 21 st century. Lisbon Council Policy Brief, vol. VI, no. 3, pp. 24-25.

Wonglimpiyarat J. (2016). Challenges for China's banks: Investment policies to support technology-based start-ups. Technology in Society, vol. 46, pp. 49-57.

\section{Information about the authors}

\section{Mariya V. PODSHIVALOVA}

Cand. Sc. (Econ.), Associate Professor of Finance, Money Circulation and Credit Dept. South Ural State University (76 Lenina Ave., Chelyabinsk, 454080, Russia). E-mail: podshivalovamv@susu.ru

Irina S. PYLAEVA

Chief specialist of Industrial Policy Dept. of the Committee of Chelyabisnk City Economy. City Administration of Chelyabinsk (2 Revolution Square, Chelyabinsk, 454113, Russia). E-mail: econom@cheladmin.ru

\section{Nadehzda N. KUZMINA}

Cand. Sc. (Pedagogy), Associate Professor of Foreign Languages Dept. South Ural State University (76 Lenina Ave., Chelyabinsk, 454080 Russia).E-mail: kuzminann@susu.ru 
DOI: $10.29141 / 2218-5003-2019-10-1-3$

\title{
Оценка государственных программ поддержки малого бизнеса: региональный аспект
}

\author{
М.В. Подшивалова, И.С. Пылаева, Н.Н. Кузьмина
}

\begin{abstract}
Аннотация. В статье исследуется вопрос оценки государственных программ поддержки средних и малых предприятий с позиций институциональной теории. Методологической основой исследования послужила теория трансакционных издержек, что позволило развить теоретические аспекты оценки эффективности государственных программ за счет включения в анализ нового фактора - различных видов трансакционных издержек получателей средств. Поставлен вопрос об эффективности применяемых программ поддержки предпринимательства на примере Челябинска и Челябинской области. Проанализированы основные требования к претендентам, временные затраты для подготовки документов на получение субсидий, а также показатели обратной связи прошлых периодов. С одной стороны, выявлено наличие жестких требований к претендентам со стороны государственных органов. С другой - низкая востребованность программ государственной финансовой помощи со стороны СМП. Произведена оценка трансакционных издержек получателей субсидий путем перевода затрат времени в финансовые затраты. Сформулирован вывод о том, что уровень трансакционных издержек субъектов СМП при подаче заявок не является существенным. Основной причиной низкого стремления СМП к участию в конкурсе по распределению бюджетных средств представляется высокий уровень трансакционных издержек другой природы - потери, связанные с выходом из "тени" при предоставлении сведений органам власти. Практическое применение полученных результатов направлено на повышение адекватности методик оценки эффективности программ поддержки СМП институциональным ограничениям российского малого бизнеса.
\end{abstract}

Ключевые слова: малые и средние предприятия (СМП), государственная поддержка, трансакционные издержки, институциональный подход, финансы СМП.

JEL Classification: H50, E26, 017

Финансирование. Работа выполнена при финансовой поддержке постановления Правительства РФ №211, контракт № 02.A03.21.0011.

Аата поступления статьи: 15 ноября 2018 г.

Ссылка для цитирования: Подшивалова М.В., Пылаева И.С., Кузьмина Н.Н. Оценка государственных программ поддержки малого бизнеса: региональный аспект // Управленец. 2019. Т. 10. № 1. С. 28-39. DOI: 10.29141/2218-5003-2019-10-1-3.

\section{Источники}

Алещенко В.В. (2014). Пространственная асимметрия уровня развития предпринимательства и государственного финансирования программ поддержки малого и среднего бизнеса в России // Двадцатые апрельские экономические чтения: материалы Междунар. науч.-практ. конф. Омск: Омский филиал Финансового университета при Правительстве РФ. С. 8-11.

Балекин Е.В. (2010). Методические аспекты государственного управления развитием и поддержкой промышленного малого предпринимательства в Москве // Вестник Московского государственного областного университета. Сер.: Экономика. № 2. C. 137-141.

Басарева И.Г. (2010). Государственная поддержка СМП: помощь или институциональная ловушка? // XI Междунар. науч.практ. конф. по проблемам развития экономики и общества (Москва, 6-8 апреля 2010 г.): в 3 т. М. Т. 2. С. 171-179.

Белова И.А., Бархатов В.И., Плетнев Д.А. (2016). Влияние программ поддержки малого и среднего бизнеса в России на их успешное функционирование // Методология устойчивого экономического развития в условиях новой индустриализации: сб. тр. Междунар. науч.-практ. конф. Крымский федеральный университет им. В.И. Вернадского. М.: Антиква. С. $147-151$.

Бовыкина М.Г. (2013). К вопросу об оценке эффективности государственной поддержки малого бизнеса // Леденцовские чтения. Бизнес. Наука. Образование: материалы III Междунар. науч.-практ. конф. Вологда. С. 383-390.

Бородушко И.В. (2014). Российский малый бизнес: правовое регулирование и государственная поддержка // Вестник СанктПетербургской юридической академии. Т. 4. С. 44-47.

Буев В.В., Сайдуллаев Ф.С., Шамрай А.А. (2010). Малое предпринимательство в регионах России в 2009 году. Индекс развития малого предпринимательства. М.: АНО НИСИПП.

Быкова Н.В. (2014). Современный подход к оценке эффективности государственной поддержки малого предпринимательства // Вестник Ленинградского государственного университета им. А.С. Пушкина. Т. 4. С. 107-115.

Дадашев А., Гловацкая И., Лазуренко С., Нешитой А. (2002). Эффективность поддержки малого предпринимательства // Вопросы экономики. № 7. С. 127-135.

Ежов А.Н., Лукин С.В., Ильина Л.Н., Жура С.Е., Смирнова И.Г. (2016). Оценка эффективности государственной поддержки малого бизнеса в современных условиях // Бизнес. Образование. Право. № 2. С. 29-34.

Ильясова А.В. (2015). Эффективность региональных программ поддержки малого и среднего бизнеса в Пензенском регионе // Журнал XXI век: итоги прошлого и проблемы настоящего. №6. С. 330-334.

Климова М.В. (2013). Малый бизнес в России: государственная поддержка или разорение? // Национальные интересы: приоритеты и безопасность. №31. С. 49-55.

Кремин А.Е. (2017). Методика оценки эффективности государственной поддержки малого предпринимательства в регионе // Проблемы развития территорий. № 3. С. 46-61.

Сидорчук Р.Р. (2012). Государственная и общественная поддержка малых и средних предприятий в России // Маркетинг МВА. Маркетинговое управление предприятием. № 2. С. 4-25.

Шлычков В.В., Нестулаева Д.Р., Алафузов И.Г. (2015). Малый бизнес о векторе социально-экономического развития экономики России: взгляд из региона // Вестник экономики, права и социологии. № 2. С. 97-102.

Alvarez R. (2004). Sources of export success in small- and medium-sized enterprises: The impact of public programs. International 
Business Review, vol. 13(3), pp. 383-400.

Anderson R., Kegels C. (1997). Finance and Investment in Transition: Czech Enterprises, 1993-1994. William Davidson Institute Working Papers Series 164, William Davidson Institute at the University of Michigan. Available at: https://ideas.repec.org/p/wdi/papers/1997-164.html.

Aykan E., Aksoylu S., Sönmez E. (2013). Effects of Support Programs on Corporate Strategies of Small and Medium-sized Enterprises. Procedia - Social and Behavioral Sciences, vol. 99, pp. 938-946.

Beck T., Demirgüç-Kunt A., Maksimovic V. (2008). Financing Patterns Around the World: Are Small Firms Different? Journal of Financial Economics, vol. 89, pp. 467-487.

Beck T., Demirgüç-Kunt A., Laeven L., Maksimovic V. (2006). The Determinants of Financing Obstacles. Journal of International Money and Finance, vol. 25(6), pp. 932-952.

Bondareva I., Zatrochová M. (2014). Financial Support for the Development of SMEs in the Slovak Republic. Procedia Social and Behavioral Sciences, vol. 110, pp. 541-548.

Budina N., Garretsen H., Jong E. de (2000). Liquidity Constraints and Investment in Transition Economies: The Case of Bulgaria. Economics of Transition, vol. 8, pp. 453-475.

Cansino J.M., Lopez-Melendo J., Pablo-Romero M.D.P., Sánchez-Braza A. (2013). An economic evaluation of public programs for internationalization: The case of the Diagnostic program in Spain. Evaluation and Program Planning, vol. 41, pp. 38-46.

Castillo J.A., Mora-Valencia A., Javier Perote J. (2018). Moral hazard and default risk of SMEs with collateralized loans. Finance Research Letters, vol. 26 (Sept.), pp. 95-99. Available at: https://doi.org/10.1016/j.frl.2017.12.010.

Francis J., Collins-Dodd C. (2004). Impact of export promotion programs on firm competencies, strategies and performance: The case of Canadian high-technology SMEs. International Marketing Review, vol. 21(4-5), pp. 474-495.

Freixanet J. (2012). Export promotion programs: Their impact on companies' internationalization performance and competitiveness. International Business Review, vol. 21(6), pp. 1065-1086.

Gençtürk E.F., Kotabe M. (2001). The effect of export assistance program usage on export performance: A contingency explanation. Journal of International Marketing, vol. 9(2), pp. 51-72.

Gros D., Suhrcke M. (2000). Ten Years After: What is Special About Transition Countries? European Bank Working Paper, vol. 56. Available at: http://hdl.handle.net/10419/19465.

Guinness G.Mc., Hogan T., Powell R. (2018). European trade credit use and SME survival. Journal of Corporate Finance, vol. 49, pp. 81-103.

Jalali S.H. (2012). The effect of export promotion programs on export performance: Evidence from Iranian food manufacturers. International Journal of Business and Globalisation, vol. 9(2), pp. 122-133.

Lederman D., Olarreaga M., Zavala L. (2016). Export promotion and firm entry into and survival in export markets. Canadian Journal of Development Studies, vol. 37(2), pp. 142-158.

Leonidou L.C., Palihawadana D., Theodosiou M. (2011). National export-promotion programs as drivers of organizational resources and capabilities: Effects on strategy, competitive advantage, and performance. Journal of International Marketing, vol. 19(2), pp. 1-29.

Moreira D.F. (2016). The Microeconomic Impact on Growth of SMEs When the Access to Finance Widens: Evidence from Internet \& High-tech Industry. Procedia - Social and Behavioral Sciences, vol. 220, pp. 278-287.

Mrva M., Stachová P. (2014). Regional Development and Support of SMEs - How University Project can Help. Procedia - Social and Behavioral Sciences, vol. 110, pp. 617-626.

Peachey S., Roe A. (2004). Access to finance, Oxford Policy Management. Available at: www.microfinancegateway.org/gm/ document-1.9.29564/22078_access_2_finance.pdf.

Prelipcean G., Boscoianu M. (2014). A Hybrid Framework for SME Financing Based on the Mix between Governmental Support and the Use of a Specialized Investment Fund in the Actual Context of a Slow Recovery after Crises and Turbulences. Procedia Economics and Finance, vol. 15, pp. 738-745.

Rupeika-Apoga R. (2014). Financing in SMEs: Case of the Baltic States. Procedia - Social and Behavioral Sciences, no. 150 pp. 116-125.

Tülüce N.S., Doğan I. (2014). The Impact of Foreign Direct Investments on SMEs' Development. Procedia - Social and Behavioral Sciences, vol. 150, pp. 107-115.

Uesugi I., Sakai K., Yamashiroc G.M. (2010) The Effectiveness of Public Credit Guarantees in the Japanese Loan Market. Journal of the Japanese and International Economies, vol. 24(4), pp. 457-480.

Wilthagen T. (2012). SMEs unite! In: Hofheinz P., Mettler A. SMEs in the single market - A growth agenda for the 21 st century Lisbon Council Policy Brief, vol. VI, no. 3, pp. 24-25.

Wonglimpiyarat J. (2016). Challenges for China's banks: Investment policies to support technology-based start-ups. Technology in Society, vol. 46, pp. 49-57.

\section{Информация об авторах}

\section{ПОАШИВАЛОВА Мария Владимировна}

Кандидат экономических наук, Аоцент кафедры финансов, Аенежного обращения и кредита. Южно-Уральский государственный университет (НИУ) (454080, РФ, г. Челябинск, пр. Аенина, 76). E-mail: podshivalovamv@susu.ru

\section{ПЫ/АЕВА Ирина Сергеевна}

Главный специалист отдела промышленной политики Комитета экономики города Челябинска. Администрация города Челябинска (454113, РФ, г. Челябинск, пл. Революции, 2). E-mail: econom@cheladmin.ru

\section{КУЗЬМИНА Надежда Николаевна}

Кандилат педагогических наук, Аоцент кафедры иностранных языков. Южно-Уральский государственный университет (НИУ) (454080, РФ, г. Челябинск, пр. ^енина, 76). E-mail: kuzminann@susu.ru 